\title{
Vegetable Processing At Household Level: Effective Tool Against Pesticide Residue Exposure
}

\author{
Vidisha Tomer $^{1^{*}}$, Jaswinder Kaur Sangha ${ }^{2}$ \\ 1,2 Dept. of Food and Nutrition, Punjab Agricultural University, Ludhiana
}

\begin{abstract}
Vegetables constitute an important component of a balanced diet. Being a rich source of vitamins and minerals, they protect us from micronutrient deficiencies and gastrointestinal disturbances. However, along with life-saving nutrients, they have turned into a major source of life-taking poisonous substances called pesticides and their residues into the human body. Many studies reviewed across the country have evidenced the presence of these agrochemicals in major vegetables. Presence of these persistent chemicals as residue elicits multiple health complexities ranging from mild allergies to deadly diseases. To minimise dietary exposure to pesticides, it is pertinent to explore strategies that effectively help in reducing the residue content at individual level. Several simple, labour-less and cost effective unit operations like washing, peeling and cooking singly or in combination can prove an effective means in reducing dietary consumption of pesticide residues even in poor populace. In a developing country like India, dissipation techniques at household level can serve as an effective tool in reducing risk related to dietary exposure to residues and henceforth controlling pesticide related adversities. This article is a collection of reviews that provide us the account of extent of residue reduction through commonly used processing treatments.
\end{abstract}

Keywords: Dissipation; Health hazards; Household processing treatments; Pesticide residues

\section{Introduction}

Vegetables are the inseparable components of Indian cuisine and are consumed throughout the country in different forms and preparations. They form the bulk and are the major source of vitamins and nutrients, hence fulfilling the requirements of our balanced diet. Vegetables are low in fat and are rich in vitamins and minerals. They are rich sources of calcium, magnesium, potassium, iron, beta-carotene, vitamin B-complex, vitamin- $\mathrm{C}$, vitamin A and vitamin $\mathrm{K}$. Apart from supplying micronutrients; they are home for antioxidants too; hence protect the human body from oxidative stress, diseases and improve immunity. Additionally, they are loaded with soluble and insoluble fibers viz; cellulose, hemi-cellulose, gums, pectin. These fibres retain excessive water and maintain colon health. Hence, they are necessary for good health.

\subsection{Vegetable Consumption Status}

\section{Background}

Modernization of agriculture has played a pivotal role in increasing the production of vegetables. Today, India is one of the leading producers of vegetables and is reaching new heights every day. In spite of all these facts, the consumption of vegetables in India is found below the recommended dietary intake set by ICMR in almost all the states. Low fruit and vegetable intake is one of the major contributing factors for the prevalence of micronutrient deficiencies in Indians [1]. Vegetable consumption has found to be quite low in almost all states except Orissa and West Bengal (Fig. 1).

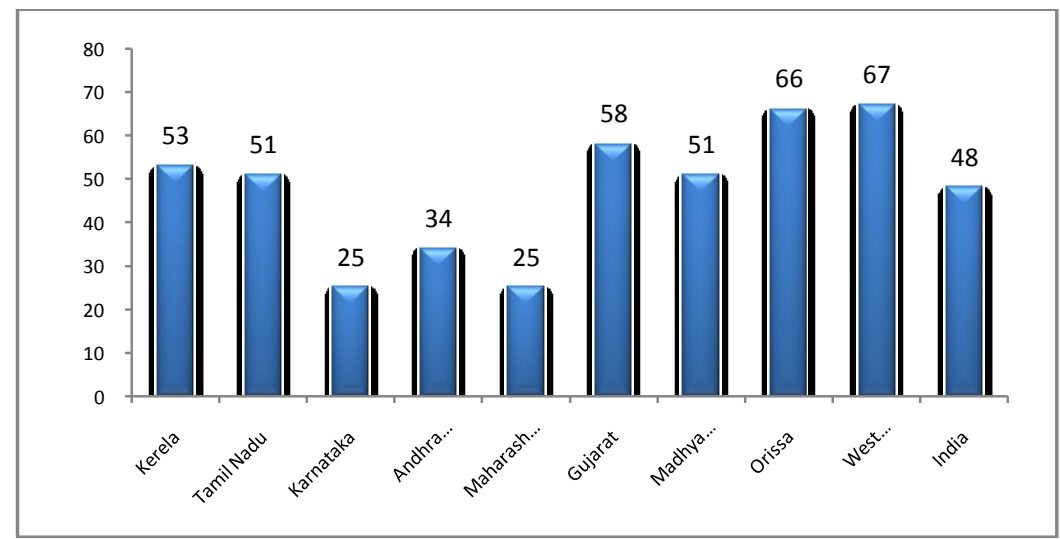

Fig. 1: Mean household consumption of vegetables $\left(\mathrm{gmCU}^{-1}\right.$ day $\left.{ }^{-}\right)$in different states of India (Adapted from [2]) 


\subsection{Need for pesticides:}

Vegetable crops are highly sensitive to pest attacks. Even today about $30-40 \%$ of the vegetables grown are damaged by pest attacks. This is where the use of agrochemicals called pesticides comes into picture. Pesticides can be defined as a group of poisonous harmful chemicals that were applied to plants and their fruits to save them from getting damaged from pests. In India, the use of pesticides on agricultural crops started during the mid-sixties after the launching of the green revolution. It provided a breathing spell for achieving balance between growing population and food security [3]. Henceforth, they were used as an element in achieving sustainable food security effectively. Since then these Agrochemicals have been used by vegetable growers for enhancing productivity and earning huge profits in return. Today, India is the leading producer and exporter of different vegetables. It shares about $13 \%$ of the world's output of vegetables from only $2 \%$ of cropped area in the country. However, achieving monetary benefits is not the only reason for the use of pesticides. Looking at the other side, India is the second most populated country in the world. In order to achieve vegetable security for each and every individual in the country, vegetable production has to be doubled roughly in a decade's time [4]. Therefore, they are sprayed frequently several times in their lifecycle. Vegetables are exposed to pesticides at several stages starting with the treatment of the seeds. Initially, seeds are treated with herbicides to protect them from fungal infestation and then sowed. After sprouting, the cycle of repeated use of pesticides starts on the standing crops to control pest infestation.

\section{Presence of pesticides in vegetables}

Spraying of crops with different formulations of pesticides and their adsorption to soil particles is attributed to be the prime reason for contamination of vegetables. However, contamination because of the movement of these agrochemicals has always been underestimated. Motility of pesticides from one crop to another and their transport over long distances by means of wind, rainfall and running water streams has led to contamination of crops even in far off lands. Residues of pesticides sprayed on previous crops have also been found as contaminants in the vegetables. Vegetable samples collected from different states all over the country have evidenced the presence of pesticide residues in them. State wise distribution of such studies has been reviewed in Table 1. Highest rate of contamination has been observed in Haryana, Bihar, Delhi and Karnataka.

Table 1: Presence of Pesticides in vegetables in different states of India.

\begin{tabular}{|c|c|c|c|c|c|}
\hline State & Vegetables & $\begin{array}{l}\text { Percent } \\
\text { contami } \\
\text { nation }\end{array}$ & $\begin{array}{l}\text { Percen } \\
\quad t \\
\text { above } \\
\text { MRL }\end{array}$ & Pesticides detected & $\begin{array}{c}\text { Refere } \\
\text { nces }\end{array}$ \\
\hline $\begin{array}{l}\text { Rajastha } \\
\mathrm{n}\end{array}$ & $\begin{array}{l}\text { Cauliflower, brinjal, tomato, } \\
\text { okra, cabbage, potato }\end{array}$ & 40.11 & 35.62 & $\begin{array}{l}\text { Endosulfan, Cypermethrin, Methyl } \\
\text { parathion, Fenvalerate and } \\
\text { Monocrotophos, methyl parathion, } \\
\text { Quinalphos }\end{array}$ & {$[5]$} \\
\hline \multirow[b]{2}{*}{$\begin{array}{c}\text { Uttar } \\
\text { Pradesh }\end{array}$} & Cabbage, Okra, tomato, Brinjal & 41.67 & 13.33 & $\begin{array}{l}\text { Benzene Hexa Chloride, Chlorpyrifos, } \\
\text { Cypermethrin, butachlor, chlordane. } \\
\text { Monochrotophos }\end{array}$ & {$[6]$} \\
\hline & $\begin{array}{l}\text { Bitter gourd, jack fruit, french- } \\
\text { bean, onion, pointed gourd, } \\
\text { capsicum, spinach, potato, } \\
\text { fenugreek seeds, carrot, radish, } \\
\text { cucumber, beetroot, brinjal, } \\
\text { cauliflower, cabbage, tomato, } \\
\text { okra and bottle gourd }\end{array}$ & 52.38 & 20.00 & $\begin{array}{l}\text { HCH, Dicofol, -Endosulfan, } \\
\text { Fenpropathrin, Permethrin-II, } \beta \text { - } \\
\text { cyfluthrin-II, Fenvalerate-I, Dichlorvos, } \\
\text { Dimethoate, Diazinon, Malathion, } \\
\text { Chlorofenvinfos, Anilophos, and } \\
\text { Dimethachlor }\end{array}$ & [7] \\
\hline $\begin{array}{c}\text { West } \\
\text { Bengal }\end{array}$ & Fenugreek, coriander, sugatbeet & $\begin{array}{l}2.16 \\
\mathrm{ng} / \mathrm{g}\end{array}$ & & Aldrien, dieldrien, Heptachlor, Lindane & {$[8]$} \\
\hline $\begin{array}{l}\text { Uttarakh } \\
\text { and }\end{array}$ & $\begin{array}{l}\text { Brinjal, Okra, tomato, sweet- } \\
\text { pepper, cabbage, cauliflower }\end{array}$ & & & $\begin{array}{l}\text { Endosulphan, carbendazim, chlorpyrifos, } \\
\text { cypermethrin, imidachloprid }\end{array}$ & [9] \\
\hline Bihar & $\begin{array}{l}\text { Brinjal, Cauliflower, cabbage, } \\
\text { green chilly }\end{array}$ & 69 & 11 & Cypermethrin & {$[10]$} \\
\hline Haryana & $\begin{array}{l}\text { Okra, bitter gourd, smooth/ridge } \\
\text { gourd, cucumber, tomato, Brinjal }\end{array}$ & 100 & 23 & $\begin{array}{l}\text { HCH, DDT, DDE, Aldrin, Endosulfan, } \\
\text { Endosulfan sulphate, Permethrin, } \\
\text { Cypermethrin, Deltamethrin, Fenvalerate }\end{array}$ & {$[11]$} \\
\hline $\begin{array}{l}\text { Andhra } \\
\text { Pradesh }\end{array}$ & Tomato, Brinjal & 45.5 & 4 & $\begin{array}{l}\text { Endosulphan, Monochrotophos, } \\
\text { Cypermethrin }\end{array}$ & {$[12]$} \\
\hline $\begin{array}{l}\text { Jharkhan } \\
\text { d }\end{array}$ & Cauliflower, Brinjal, Okra & 48.7 & 15.37 & Endosulfan & [13] \\
\hline $\begin{array}{l}\text { Andama } \\
\mathrm{n} \text { Islands }\end{array}$ & $\begin{array}{l}\text { Brinjal, Okra, Green chilli, } \\
\text { Crucifers, Cucurbits }\end{array}$ & 34 & 15.3 & $\begin{array}{l}\text { Endosulfan, Cypermethrin, fenvalerate, } \\
\text { fluvalinate I, Deltamethrin, Cyhalothrin, } \\
\text { Chlorpyrifos, profenophos, } \\
\text { monochrotophos, ethion, dimethoate }\end{array}$ & {$[14]$} \\
\hline Delhi & Vegetables & 100 & 31 & Cypermethrin, endosulfan & {$[15]$} \\
\hline
\end{tabular}


Vegetable Processing At Household Level: Effective Tool Against Pesticide Residue Exposure

\begin{tabular}{|c|c|c|c|c|c|}
\hline & Vegetables & 71 & 18 & $\begin{array}{l}\text { Endosulfan, chlorpyrifos, M Parathion, } \\
\text { Quinalphos, Monochrotophos }\end{array}$ & {$[16]$} \\
\hline Punjab & Cauliflower & 42 & - & $\begin{array}{l}\text { Endosulfan, Endosulfan sulphate, } \\
\text { Acephate, chloroyriphos, fenamiphos, } \\
\text { profenophos, quinalphos, cyhalothrin, } \beta \text { - } \\
\text { cyfluthrin, fenpropathrin }\end{array}$ & [17] \\
\hline Kerela & Basil, Spinach & & $16-78$ & Endosulfan & [18] \\
\hline $\begin{array}{c}\text { Karnata } \\
\text { ka }\end{array}$ & Beans, brinjal, cabbage, carrot & 100 & 58 & $\begin{array}{l}\text { Aldrien, Dieldrien, endosulphan, } \mathrm{HCH} \text {, } \\
\text { heptachlor, acephate, chlorpyrifos, } \\
\text { monochrotophos, phorate profenophos, } \\
\text { cypermethrin, deltamethrin, cyhalothrin }\end{array}$ & [19] \\
\hline
\end{tabular}

\section{Health impacts associated with pesticides}

Excessive use of pesticides can harm the ecosystem leading to several health impacts. Dr. MS Swaminathan feared and cautioned about the health impacts associated with the use of these persistent chemicals shortly before the launch of the green revolution. In his presidential address to the Agricultural Science Section of the Indian Science Congress in early January 1968 [20], he stated-

".....exploitative agriculture offers great possibilities if carried out in a scientific way, but poses great dangers if carried out with only an immediate profit motive...........Indiscriminate use of pesticides, fungicides and herbicides could cause adverse changes in biological balance as well lead to an increase in the incidence of cancer and other diseases, through the toxic residues present in the grains, vegetables or other edible parts.........".

Decades later, his findings then have become the happening of today. What he feared almost forty-five years ago has today become a harsh reality. Uncontrolled use of pesticides, particularly at the fruiting stage and non-adoption of safe waiting periods has led to their accumulation in vegetables. It has landed us in the world full of complex health related adversities and exponentially increased burden of deadly diseases. The residues being persistent in nature infiltrate crops, contaminate water, pollute complete food chain and enter our body through diet. Many accidents have been reported in different parts of the world due to injudicious and indiscriminate use of pesticides. Developing countries suffer $99 \%$ of deaths from pesticide poisoning [21].

Pesticide exposure may produce biochemical alterations in the body long before adverse clinical health effects are manifested [22]. In spite of the well known fact that pesticide residues are responsible for a great deal of complexities, the adverse health effects cannot be correlated with exposure to a single pesticide. Multiple and prolonged pesticide exposure affect different organ systems differently [23]. Health effects from pesticides and their residues may range from mild allergies, rashes and breathing difficulties to deadly diseases like cancers etc. Cancers of all types have been reported on pesticide exposure including leukaemia, lymphomas, soft tissue sarcomas, brain, bone and stomach cancers. Pesticides known as endocrine disruptors are found to cause neurotoxicity, which elicit their adverse effects by mimicking or antagonising natural hormones in the body. It leads to confusion, irritability, drowsiness and even Alzheimer and Parkinson disease. Adversities related to reproductive system include irregular menstrual cycles, infertility, hypospadias, cryptorchidism, decreased penile length, low sperm counts, disruption of male and female hormone signalling pathway, still births and even foetal death $[24,25]$.

\subsection{Locale of the residues}

\section{Mechanisms of post-harvest dissipation of Pesticide residues}

Pesticides can be applied to fruits and vegetables during various phases of production. Some pesticides are applied before blooming while others at the growing stage and/or later at the time of harvesting. Depending on the location, pesticides are classified as systemic and contact [26]. Pesticides that are absorbed by the plant surface (waxy cuticle and roots) enter the plant transport system are termed as systemic pesticides. Contact pesticides remain on the surface of the plant. The concentration of pesticides was found to be higher in fruit stalk on exocarp and food receptacle in fruits and vegetables. In leafy vegetables, residue concentration was higher in the outer leaves than the inner ones [27].

\subsection{Degradation mechanisms}

Fate refers to the pattern of distribution of an agent, its derivatives and metabolites in an organism as a result of transport, partitioning, transformation or degradation [28]. Rate of pesticide movement and dissipation is based on the physiochemical properties and interaction with environmental factors. After application on the crops they may follow different pathways depending on the composition and physiochemical properties of vegetables and pesticides. It is the interaction between the combination of the properties of pesticides and vegetables with environmental factors that determines the extent of pesticide absorbance, penetration and degradation. After application, pesticides may interact with plant surfaces, may be exposed to environmental factors such as wind and sunlight and may be washed off during rain [29]. Their ability to resist degradation is 
measured as half-life. Half life is defined as the time in days required for half of the initial amount of pesticide to breakdown. Half life of pesticides depends upon the environmental conditions, the type of vegetable and the amount of pesticide initially applied/present [30]. Half lives of some common pesticides in vegetables are given in Table 2.

Table 2: Half life of some common pesticides in vegetables

\begin{tabular}{|c|c|c|c|c|}
\hline Vegetable & Pesticide & Initial dose & Half-life (days) & Reference \\
\hline \multirow{3}{*}{ Brinjal } & \multirow{2}{*}{ Benfuracarb } & $0.25 \mathrm{mgkg}^{-1}$ & 3.90 & \multirow{2}{*}[31]{} \\
\hline & & $0.50 \mathrm{mgkg}^{-1}$ & 4.73 & \\
\hline & Endosulphan & $4.5 \mathrm{mgkg}^{-1}$ & 3.30 & {$[32]$} \\
\hline \multirow{2}{*}{ Pepper } & Pirimophos-methyl & $10.49 \mathrm{mgkg}^{-1}$ & 1.72 & \multirow{2}{*}[33]{} \\
\hline & Profenophos & $10.67 \mathrm{mgkg}^{-1}$ & 1.74 & \\
\hline \multirow{2}{*}{ Chilly } & Multiresidue extraction & & 3.22 & [34] \\
\hline & Fubendiamide & 60 ga.i./ha & 0.96 & [35] \\
\hline \multirow{4}{*}{ Okra } & Flubendiamide & $0.28 \mathrm{mgkg}^{-1}$ & 4.7 & {$[36]$} \\
\hline & Fenazaquin & 125 ga.i./ha & 3.13 & [37] \\
\hline & Propargite & $1.36 \mathrm{mgkg}^{-1}$ & 0.79 & [38] \\
\hline & $\beta$-cyfluthrin & & 0.91 & [39] \\
\hline Tomato & Bifenthrin & $25 \mathrm{~g}$ a.i ha & 1.83 & [40] \\
\hline
\end{tabular}

Apart from half-life, dissipation of pesticides residues can also be explained through some basic processes viz; Volatilisation, hydrolysis, metabolism, enzymatic transformation, oxidation etc.

\subsubsection{Volatilisation}

It is the ability of the pesticide to vaporize or evaporate after application in the field. It is dependent on the vapor pressure of the pesticide. Pesticides with high vapor pressure tend to volatilize rapidly into the air while those with low vapor pressure remain longer on the surface. Volatilization rate also depends on the environmental factors such as wind speed and temperature. The faster the wind speed and the higher the temperature the more the pesticide will evaporate.

\subsubsection{Hydrolysis}

Hydrolysis is the breaking of the bonds in the presence of water. After cleavage, a new bond is formed by taking oxygen atom of water, hence introducing $\mathrm{HOH}$ or $\mathrm{OH}$ into the molecule. Products obtained after hydrolysis are more polar than the molecules from which they are derived and may be more water soluble and less subject to bioaccumulation. Hydrolysis is both biotic and abiotic types. Abiotic hydrolysis of pesticides usually takes place in low biological activity. Rate of hydrolysis depends upon the hydrogen ion concentration $(\mathrm{pH})$ and acid-base characteristics $\left(\mathrm{pK}_{\mathrm{a}}\right)$. The rate of hydrolysis of pesticides increases with increasing temperature [41].

\subsubsection{Photolysis}

Degradation of pesticides on exposed surfaces may be facilitated in the presence of sunlight by a phenomenon called photolysis. The process of photolysis results in pesticide degradation through direct and indirect pathways. In direct photolysis, molecules absorb energy from the sunlight especially in the UV-visible range resulting in pesticide degradation. In indirect transformation, absorption of photon leads to phototransformation of some other chemical compound excluding pesticides. These compounds, called sensitizers, undergo break down and get activated by sunlight. These sensitizers in return react with pesticides and are responsible for affecting pesticide molecules. Photolysis is insensitive to temperature and $\mathrm{pH}$. However, it is affected by spectral distribution, intensity \& duration of sunlight and angle of incidence of sunlight to the exposed surface. Photolysis produces oxidation products which are more water soluble, less volatile and less subject to bio-uptake than their parent molecule.

\subsubsection{Microbial metabolism}

Some pesticides may be degraded by microbial metabolism. Micro-organisms can use pesticides as nutrients thereby breaking them into carbon dioxide and other components [41]. Because of the difference between naturally occurring organic chemicals and pesticide structures, they cannot be assimilated by the microbes but they may be altered at reactive sites. The products formed may be less or more toxic than the parent chemical.

Environmental degradation viz; Photodegradation and many other degradation mechanisms generally cease to function or are greatly reduced once a crop is removed from the field situation. Hence it is necessary to apply several processing treatments even at the household level to reduce pesticide residues. 


\section{Household processing treatments for reduction of pesticide residues}

Food processing techniques in vegetable processing implies the set of methods and unit operations used to transform raw ingredients into edible forms for direct consumption either in the home or by the food processing industry. Reviewing extensive literature showed that in most cases these steps lead to considerable reductions in residue levels in the prepared food, particularly through, washing and peeling, fermentation, refrigeration singly or in combination. The behaviour of residues in storage and processing can be rationalized in terms of the physico-chemical properties of the pesticide and the nature of the process [42].

Transition of processed products from raw agricultural commodities through food processing results in change in concentration in pesticide residues. This change in concentration is often measured by transfer factors or food processing factors (Pf). These processing factors are expressed (1) as the concentration of pesticide after processing divided by the concentration before processing [43].

$$
\text { Processing factor }(\mathrm{Pf})=\frac{\text { Concentration } \quad \text { of Pesticide after processing }}{\text { Concentration of pesticide before processing }}
$$

The risk of exposure to organophosphorus pesticides in Dutch diet was assessed using processing factors [44]. General processing factors were derived to be 0.76 for washing, 0.44 for peeling and 0.74 for canning of fruits and vegetables. Washing processing factors were $0.9 \pm 0.3$ for pyridaben, $1.1 \pm 0.3$ for pyrifenos and $1.2 \pm 0.5$ for tralomethrin in tomato [45].

The impact of each unit operation commonly practiced at household level is explained hereafter.

\subsection{Washing}

Washing of vegetables is the most traditional and the preliminary unit operation applied to remove debris and dirt from vegetables prior to consumption. It is the most prevalent practice in every household as it is the cheapest and easiest method of cleaning [46]. Vegetables can be washed by using plain water or by chemical formulations in commercial and household processing. Formulations commonly used are brine, chlorine solution, ozonated water, strong acid, baking soda, vinegar, lemon water, potassium permanganate etc $[47,48$, 49]. The extent of residue reduction by washing depends on the physiochemical properties of the pesticides, such as water solubility, hydrolytic rate constant, volatility and octanol-water partition coefficient (Pow), in conjunction with the actual physical location of the residues; washing processes lead to reduction of hydrophilic residues which are located on the surface of the crops.

Surface residues are amenable to simple washing operations whereas systemic residues present in tissues are little affected. For example, in tomatoes, systemic methamidaphos was the only one that could not be removed from a group of pesticides by washing [50]. Pyrethroids and some organophosphates being nonsystemic in nature remain attached as microparticles on the surface and are easily removed by the mechanical stirring with water during washing. Thus washing has a significant effect on the removal of residues in several vegetables depending on the pesticide because of less/no penetration of the chemical into the cuticle layer of the plant surface and resulting in deposits removable by washing. These results agree with those obtained by several researchers [51,52] who reported $50-60 \%$ removal of the residues by the washing operation. A reduction of $10-30 \%$ of alphamethrin residues in tomato and eggplant have been reported [68]. Washing reduced $90 \%$ of pesticides from carrots [53]. Effectiveness of washing in dislodging pesticide residues in different vegetables has been synthesized in Table 3 .

\subsubsection{Washing by Tap Water}

Tap water washing is the most commonly followed practice in every household before the processing of vegetables. Effectiveness of washing operation was checked in vegetables based on the solubility of pesticides. Plain water washing reduced fat soluble residues of bifenthrin, endosulphan and profenofos in cauliflower by $25 \%, 28.1 \%$ and $14.32 \%$ respectively. Degree of reduction on plane water washing on water soluble pesticides namely deafenthiuron, imidacloprid in cauliflower were to be $40.69 \%, 39.07 \%$ and $2117 \%$ respectively [54]. Deltamethrin was reduced by washing upto $35 \%$ in tomato, $32 \%$ in cauliflower, $26 \%$ in potato and $10 \%$ in spinach [55]. Washing reduced cypermethrin residues by $33.42-35 \%$ and decamethrin by $25-27.90 \%$ in brinjal. Chlopyriphos residues were found to get reduced by 33\% in Spinach, 30\% in potato, $25 \%$ in cauliflower and $10 \%$ in tomato [56]. Imidacloprid residues reduced from $0.31-0.082 \mathrm{ppm}$ in okra by detergent washing ( $73 \%$ removal) [57]. $\lambda$-cyhalothrin residues in tomato were reduced in the range of $37-40 \%$ by washing [58]. In cauliflower washing was found to reduce the residues of monocrotophos and para thion to the extent of 48.6-70\%. However it was found less effective in reducing phorate $(16.27 \%)$, permethrin $(6.80 \%)$ and dichlorvos (3.32\%) [59].

\subsubsection{Washing in formulated solutions}

Residues of Monochrotophos, fenitrothion and fenvalerate were removed to an extent of $41.81 \%, 100 \%$ and $100 \%$ by dipping in lemon juice, dipping in $2 \%$ tamarind solution for 5 min followed by wash tap water and 
steam cooking for $10 \mathrm{~min}$ respectively [60]. Five vegetables namely beans, eggplant, okra, cauliflower, capsicum and tomato were analysed for malathion, fenitrothion, formothion, parathion, chlorpyrifos and methyl parathion. The samples were spiked with pesticides. In unwashed samples concentrations were 8.7 for malathion, fenitothion (12.5), formothion (5.3), parathion (6.9), chlorpyrifos (7.9) and methyl parathion (6.8). Washing removed $42-89 \%$ malathion, fenitrothion and chlorpyrifos residues while formothion, parathion and methyl parathion were found to be decreased upto $20-48 \%$ [61].

Table 3: Reduction of pesticide residues by washing in some common vegetables

\begin{tabular}{|c|c|c|c|c|}
\hline Vegetable & Pesticide analysed & Initial content $\left(\mathrm{mg} \mathrm{kg}^{-1}\right)$ & Percentage reduction & References \\
\hline \multirow{9}{*}{ Okra } & $\Sigma-\mathrm{HCH}$ & & 38 & \multirow{3}{*}[62]{} \\
\hline & $\Sigma$-DDT & & 20 & \\
\hline & Endosufan & & 36 & \\
\hline & Chlorpyrifos & $1.41 \pm 0.148$ & $13-35$ & {$[63]$} \\
\hline & Cypermethrin & $1.17 \pm 0.1$ & $45-50$ & \multirow{3}{*}[64]{} \\
\hline & deltamethrin & $1.08 \pm 0.12$ & $30-35$ & \\
\hline & cyahalothrin & $0.48 \pm 0.03$ & $20-25$ & \\
\hline & Quinalphos & & $31-32$ & {$[37]$} \\
\hline & B- cyfluthrin & & $35-43$ & {$[65]$} \\
\hline \multirow{11}{*}{$\begin{array}{l}\text { Brinjal/ } \\
\text { eggplant }\end{array}$} & Endosulphan & 2.13 & $40-47$ & {$[32]$} \\
\hline & Cypermethrin & 1.57 & $20-25$ & {$[66]$} \\
\hline & Carbofuran & & 21 & {$[62]$} \\
\hline & Deltamethrin & $0.174 \pm 0.018$ & 20 & {$[55]$} \\
\hline & DDT & $0.056-0.178$ & 37 & {$[62]$} \\
\hline & Decamethrin & 1.095 & $30-42$ & {$[67]$} \\
\hline & Alphamethrin & & $29-16$ & {$[68]$} \\
\hline & Quinalphos & 4.78 & $21-61$ & \multirow{2}{*}{ [69] } \\
\hline & Methomyl & 3.98 & $21-61$ & \\
\hline & Flufenzin & & $43-48$ & \multirow{2}{*}[70]{} \\
\hline & Fenpyrozimate & & $46-55.6$ & \\
\hline \multirow{9}{*}{ Tomato } & $\lambda$-cyhalothrin & & $37-40$ & {$[71]$} \\
\hline & Bifenthrin & & $17-19$ & [40] \\
\hline & ethylenethiourea & & 70 & {$[72]$} \\
\hline & Benomyl & & 83 & [73] \\
\hline & Deltamethrin & 0.00855 & $47-50$ & {$[74]$} \\
\hline & Endosulphan & 2.9 & 41.3 & \multirow{4}{*}[75]{} \\
\hline & Fenvalerate & 1.5 & 15.6 & \\
\hline & Chlorpyriphos & 1.6 & 38.2 & \\
\hline & Malathion & 2.8 & 52.0 & \\
\hline \multirow{8}{*}{ Cauliflower } & Chlorpyrifos & 9.0 & 78.6 & \multirow{5}{*}[75]{} \\
\hline & Quinalphos & 24.8 & 28.9 & \\
\hline & Endosulfan & 14.6 & 34.1 & \\
\hline & Fenvalerate & 10.5 & 65.1 & \\
\hline & deltamethrin & 2.5 & 50.8 & \\
\hline & chlorantraniliprole & & $17-40$ & {$[76]$} \\
\hline & Dichlorvos & 91.51 & 3.32 & \\
\hline & Monocrotophos & 2.54 & 70 & {$[/ 7]$} \\
\hline Cabbage & Quinalphos & & $27.72-32.48$ & {$[78]$} \\
\hline \multirow{3}{*}{ Asparagus } & Chlorpyriphos & & 24 & \multirow{3}{*}[52]{} \\
\hline & Cypermethrin & & 35 & \\
\hline & ethylenebisdithiocarbamates & & 52 & \\
\hline \multirow{2}{*}{ Ginger } & Trifloxystrobin & 0.005 & $\mathrm{ND}^{*}$ & \multirow{2}{*}{ [79] } \\
\hline & Fosthiazate & 0.003 & $\mathrm{ND}^{*}$ & \\
\hline \multirow{2}{*}{$\begin{array}{l}\text { Green } \\
\text { Chilli }\end{array}$} & Acetamiprid & 0.015 & 46.67 & \multirow{2}{*}[79]{} \\
\hline & Trifloxystrobin & 0.064 & 20.31 & \\
\hline \multirow{2}{*}{ Spinach } & Azoxystrobin & 0.004 & 100 & [79] \\
\hline & Endosulfan & $1.25 \pm 0.044$ & 22.22 & {$[80]$} \\
\hline & Trichlorfon & 0.41 & 53.7 & \\
\hline & Dimethoate & 0.46 & 32.6 & \\
\hline Cucumber & Dichlorvos & 0.84 & 52.4 & {$[81]$} \\
\hline & Fenitrothion & 0.45 & 26.7 & \\
\hline & Chlorpyrifos & 0.81 & 62.9 & \\
\hline & Metalaxyl & 1.45 & 28.97 & \\
\hline & Mancozab & 9.92 & 39.92 & {$[82]$} \\
\hline I omato & Ethylenethiourea & 2.03 & 39.41 & \\
\hline & Carbendazim & 0.28 & 29.34 & {$[83]$} \\
\hline & Endosulfan & $0.177 \pm 0.003$ & 20.34 & {$[80]$} \\
\hline Potato & Deltamethrin & $0.023 \pm 0.003$ & 26.09 & [55] \\
\hline
\end{tabular}

* Not detectable. 


\subsection{Heat Treatments}

Processes involving heat can enhance volatilization of chemicals and their hydrolysis thus reducing residue levels. Depending upon the chemical properties of pesticides different heat treatments had different impact on residue content. Sun drying reduced up to $93 \%$ fat soluble and $96 \%$ water soluble pesticides; dehydration is reported to reduce (up to $84 \%$ of fat soluble and $87 \%$ of water soluble pesticide) and blanching (up to $72 \%$ of fat soluble and $79 \%$ of water soluble pesticide [54]. Dislodging of cypermethrin residues was observed more in grilling $(50.12 \%)$, followed by cooking in oil $(45.2 \%)$, cooking in water $(41.4 \%)$, and microwave cooking $(40.89 \%)$ [66].

\subsubsection{Blanching and Boiling}

Blanching treatment was also found effective traditional method by which residues of emamectin benzoate, diafenthiuron and imidacloprid were reduced up to $55.94,68.69$ and $79.11 \%$, respectively from an initial concentration of $1.040,0.052$ and $1.010 \mathrm{ppm}$ respectively [54].

Cooking lowered deltamethrin residues from 19 to $40 \%$ in vegetables [55]. Boiling reduced OPs by $32-$ $100 \%$ in brinjal, cauliflower and okra. By boiling process maximum (100\%) reduction of OP insecticides was observed in brinjal followed by $92 \%$ in cauliflower and $75 \%$ in okra [62]. Boiling reduced trifloxystrobin residues in green chillies from initial concentration of $0.064 \pm 0.0409$ to $0.023 \pm 0.0108$ depicting a reduction of upto $50 \%$ [79]. Stir frying reduced trifloxystrobin residues from $0.064 \pm 0.0409$ to $0.030 \pm 0.0157$ in green chillies [79]. Pre-heating, pulping, evaporation and half-pasteurization increased deltamethrin $2.33 \%$ while decreasing endosulfan $66.5 \%$ after washing. The whole process decreased endosulfan and deltamethrin, $76.8 \%$ and $46.3 \%$, respectively. The residues were mostly collected in pomace [74]. Boiling reduced the residues of organophosphates in tomato, bean, okra, eggplant, cauliflower and capsicum by 52-100 \% [61].

\subsection{Peeling}

Peeling of root, tuber and bulb vegetables with a knife is common household practice. As pesticides are applied on the outer surfaces of vegetables they undergo very little amount of penetration in the cuticle. Therefore, their residues are mostly confined in the peel where they are amenable to removal by peeling or trimming. The removal of the outer part of peeling is the most effective household processing operation for pesticide removal from vegetables and reduces large fractions of residues.

Peeling reduced $73 \%$ chlorpyrifos, $82 \%$ lindane, $75 \%$ cypermethrin and $77 \%$ ethylene bisthiocarbamatein in asparagus [52]. Peeling reduced deltamethrin residues to 76 to $80 \%$ and cooking further lowered it from 19 to $40 \%$ in all tested vegetables [55]. Peeling of potatoes reduced $91-98 \%$ chlorpropham residues from an initial concentration of $3.8 \mathrm{ppm}$ in tubers 10 days after application [84]. Diazinon levels in cucumbers decreased by $67.3 \%$ from an initial level of $0.822 \mathrm{ppm}$ [85]. Malathion residues were reduced by more than $45.9 \%$ and $60.6 \%$ in cucumbers by peeling [86].Peeling reduced procymidone $(0.86 \mathrm{ppm})$ level by $77 \%$ in tomatoes [88]. Washing plus peeling removes $99 \%$ of carbaryl and malathion residues from tomatoes. Peeling processing factors were $0.3 \pm 0.2(70 \%$ reduction) for pyridaben and $0.0+/-0.0$ (100\% reduction) for both pyrifenox and tralomethrin in tomato [45].

\subsection{Fermentation}

Fermentation is a simple process during which the enzymes hydrolyze most of the proteins to amino acids and low molecular weight peptides; starch is partially converted to simple sugars which are fermented primarily to lactic acid, alcohol and carbon dioxide [88].

In a study, fermentation of cucumbers leads to significantly lower amount of benomyl and mancozeb [89]. Fermentation of vegetable mix (Tomato, celery, green bean, cabbage, cauliflower) by lactic acid bacteria for a period of $48 \mathrm{hrs}$ reduced malathion residues from an initial concentration of $3.5 \mathrm{mgkg}-1$ to $0.5 \mathrm{mgkg}-1$. However, Diazinon showed a decrease of only $0.1 \mathrm{mg} \mathrm{kg}-1$ from an initial concentration of $0.5 \mathrm{mg} \mathrm{kg}-1$ [90]. Effect of different processing treatments on pesticide residues have been reviewed in Table 4 .

\subsection{Freezing and Refrigeration}

Low temperature storage is a common method of food preservation which slows both food decay and most chemical reactions [91]. Zhang et al estimated the pesticide residue levels in cabbage after preserving in the refrigerator and found decreased pesticide residues after refrigeration [92]. In a study it was found that when cucumbers contaminated at level of $2 \mathrm{~L} / 1000 \mathrm{~L}$ in water were refrigerated the reduction of residues were $5.3 \%$, $22.4 \%, 43.7 \%, 52 \%$ and $68.2 \%$ after $2,4,6,8$ and 10 days with diazinon and $14.7 \%, 28.2 \%, 49.1 \%, 63 \%$ and $74.7 \%$ loss after these specific days with malathion, respectively [86]. Brinjals stored at refrigerated temperature showed a decline of $3.95,1.70,1.35$ and 1.1 respectively after $0,3,5$ and 7 days from an initial dose of $4.5 \mathrm{mg}$ $\mathrm{kg}^{-1}$. A decline of $72.1 \%$ was observed on the seventh day under refrigerated conditions [32]. 
Vegetable Processing At Household Level: Effective Tool Against Pesticide Residue Exposure

Table 4: Reduction of pesticide residues by different processing treatments

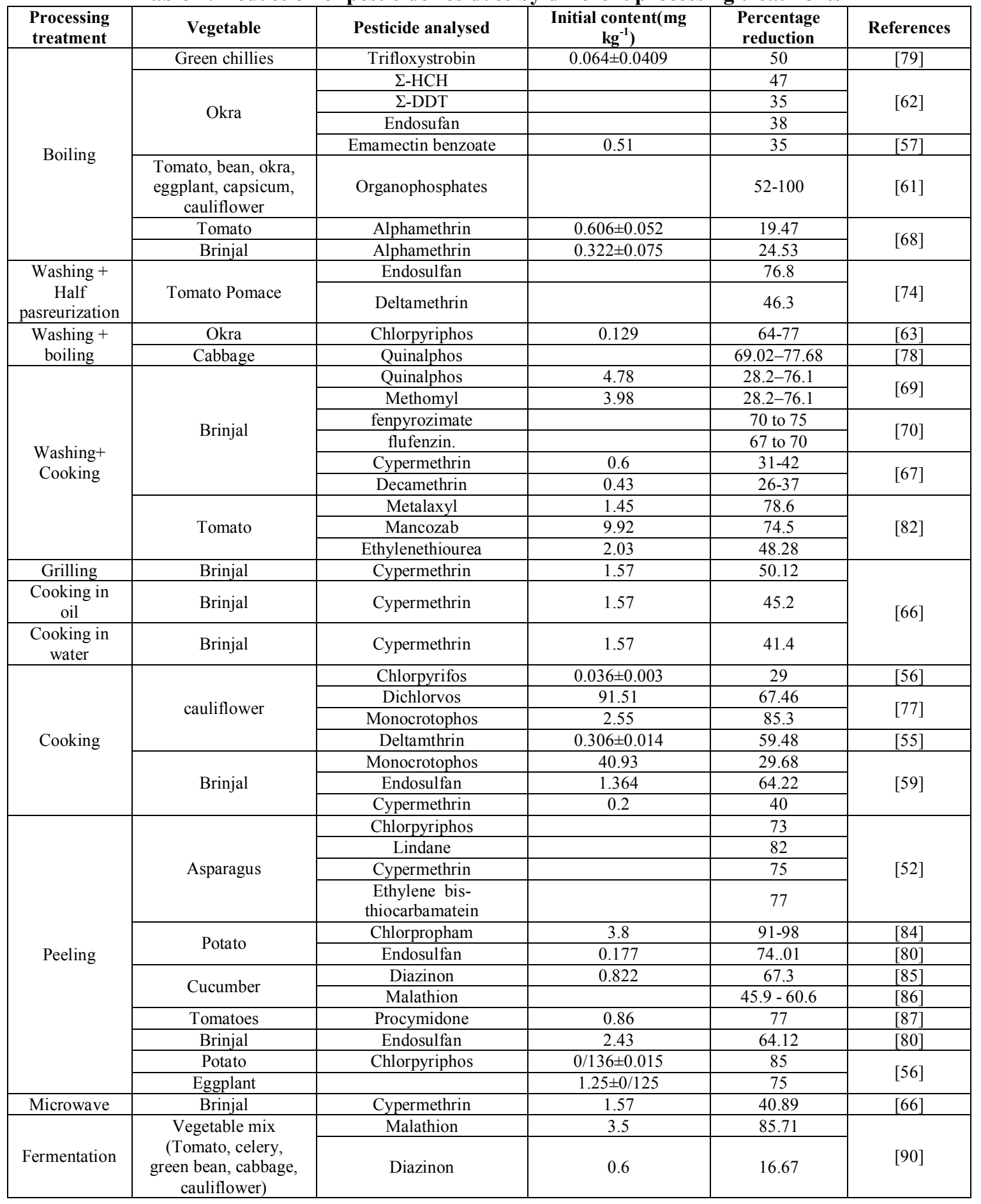

\section{Conclusion}

India, being an agrarian economy is dependent on agriculture for its development. Use of pesticides on vegetables is an inevitable part of agriculture but their unscientific usage can cause significant health adversities. There is a need to regulate pesticide intake for leading a healthy life. In a developing country like India, where quite a large proportion of the population lives below poverty line burden of deadly diseases can be a great curse. From the extensive review collected on the extent of dissipation of pesticide residues and mechanisms involved during household processing techniques, it is concluded that these can serve as an effective tool for reduction of residues within safe limits. However, there is dearth of knowledge involving exact mechanism of action by which different processing treatments ought to reduce pesticide residues in different food items. 


\section{References}

[1] U. Kanungsukkasem Fruit and vegetable consumption in rural adults population in INDEPTH HDSS sites in Asia. Global Health Action, 2009, 35-48.

[2] N. Arlappa, A. Laxmaiah, N. Balakrishna and G.N.V. Brahmam, Consumption pattern of pulses, vegetables and nutrients among rural population in India, African Journal of Food Science 4(10): 2010, 668-675.

[3] M. S. Swaminathan, Sustainable food and water security. Ankuram-Environment Quaterly. 1 (1), 2003, 23-33.

[4] R. Betne, Indian Vegetables: Nutrition Pack with Toxic Cocktail. Published in Toxics Link, 12/01/2011. (Retrieved on 2 April 2013).

[5] P.D. Charan, S.F. Ali, Y. Kachhawa and K.C. Sharma, Monitoring of Pesticide Residues in Farmgate Vegetables of Central Aravalli Region of Western India American-Eurasian, Journal of Agricultural \& Environmental Science, 7 (3), 2010, $255-258$.

[6] R. Bankar, A K Ray, A Kumar, K Adeppa and S Puri, Organochlorine pesticide residues in vegetables of three major markets in Uttar Pradesh, India Research Article, Acta Biologica Indica 1(1), 2012, 77-80.

[7] A.K. Srivastava, P Trivedi, M.K. Srivastava, M. Lohani and L.P. Srivastava, Monitoring of pesticide residues in market basket samples of vegetable from Lucknow City, India: QuEChERS method, Environment Monitoring Assessment, 176, 2012 , 465-472.

[8] B. Kumar, S. Kumar, M. Mishra, Dev Prakash, S.K. Singh and C.S. Sharma, Persistent chlorinated pesticide residues in selected market vegetables of root and leaf origin, Asian Journal of Plant Science and Research, 2 (3), 2012, 232-236.

[9] S. S. Chauhan, S. Negi, N. Singh, G. Bhatia and A. Srivastava, Monitoring of pesticides residues in farmgate vegetables of Uttarakhand, India, Wudpecker Journal of Agricultural Research, 1(7), 2012a, 250 - 256.

[10] S.P. Singh and N.K. Singh, Pesticide residues in farm gate vegetable samples in Bihar, Pest Management in Horticultural Ecosystems, 12 (2), 2006, 152-155.

[11] B. Kumari, V.K. Madan, R. Kumar and T.S. Kathpal, Monitoring of Seasonal Vegetables for Pesticide Residues, Environmental Monitoring and Assessment 74, 2002, 263-270.

[12] B.R. Kumari, G.V. Ranga Rao, K.L. Sahrawat, P. Rajasekhar, Occurrence of Insecticide Residues in Selected Crops and Natural Resources Bulletin of Environmental Contamination and Toxicology, 89, 2012, 187-192.

[13] D.K. Shahi, K. Nisha and A. Sharma, Monitoring of pesticide residues in market vegetables at Ranchi, Jharkhand (India), J Environ Sci Eng. 47(4), 2005, 322-325.

[14] T.P. Swarnam, A. Velmurugan, Pesticide residues in vegetable samples from the Andaman Islands, India, Environmental Monitoring Assessment, 2012, PMID: 23208759

[15] I. Mukherjee, Pesticides residues in vegetables in and around Delhi, Environ Monit Assess. 86 (3), $2003,265-271$.

[16] N.S. Tiwana, N. Jerath, G. Singh and R. Singh, Pesticide Pollution in Punjab: A Review, Asian Journal of Water, Environment and Pollution. 6, 2007, 89-96.

[17] K. Mandal and B. Singh, Magnitude and frequency of pesticide residues in farmgate samples of cauliflower in Punjab, India, Bulletin of Environmental Contamination and Toxicology, 85, 2010, 423-426.

[18] C. Tholkappian and S. Rajendran, Pesticide Application and its Adverse Impact on Health: Evidences from Kerala, International Journal of Science and Technology, 1(2), 2011, 56-59.

[19] A.S.R. Gowda and R.K. Somashekar, Evaluation of Pesticide Residues in Farmgate Samples of Vegetables in Karnataka, India, Bulletin of Environmental Contamination and Toxicology, 89(3), 2012, 626-632.

[20] M.S. Swaminathan (1968) The age of algeny, genetic destruction of yield barriers and agricultural transformation. Proc. Presidential Address, Agricultural Science Session, Fifty fifth Indian Science Congress, January 1968.

[21] C.N. Kesavachandran, M. Fareed, M.K. Pathak, V. Bihari, N. Mathur and A.K. Srivastava, Adverse Health Effects of Pesticides in Agrarian Populations of Developing Countries D.M. in Whitacre (Ed.), Rev. Environ. Contamin. Toxicol. 200, 2009, 33-51.

[22] A.D. Khan, M.M. Bhatti, F.A. Khan, S.T. Naqvi and A. Karam, Adverse effects of Pesticides Residues on Biochemical Markers in Pakistani Tobacco Farmers, Int. J. Clin. Exp. Med., 1, 2008, 274-282.

[23] R. Ogur and O.F. Tekbas, A commonly used pesticide endosulfan in diet could cause hepatomegaly and kidney tumor when combined with nitrosamines, Environ. Earth Sci. 5, 2011, 599-605.

[24] C. Bolognesi and F.D. Merlo, Pesticides: Human Health Effects, Encyclopedia of Environmental Health, 16, $2011,438-453$.

[25] W.C. Chien, C.H. Chung, J.J.K. Jaakkola, C.M. Chu, S. Kao et al., Risk and Prognostic Factors of Inpatient Mortality Associated with Unintentional Insecticide and Herbicide Poisonings: A Retrospective Cohort Study, PLoS One, 7, 2012, e45627.

[26] A. Bajwa and Sandhu, Effect of handling and processing on pesticide residues in food- A review, Journal of .food .Science and Technology, 2011, DoI: 10.1007/s13197-011-0499-5.

[27] S. Yoshida, H. Murata and M. Imaida, Distribution of pesticide residues in vegetables and fruits and removal by washing, $J$ Agric Chem Soc Japan, 66, 1992, 1007-1011.

[28] OECD (2003) Descriptions of selected key generic terms used in chemical hazard/risk assessment. OECD Series on Testing and Assessment No. 44.

[29] EG Amvrazi, Fate of Pesticide Residues on Raw Agricultural Crops after Postharvest Storage and Food Processing to Edible Portions, Prof. Margarita Stoytcheva (Ed.), Pesticides - Formulations, Effects, Fate (2011).

[30] NPIC (2011) National pesticide information Center. http//npic.orst.edu/envir/efate.html, (accessed February 9, 2013).

[31] R. Chandra, A. Srivastava and P.C. Srivastava, Fate of benfuracarb insecticide in mollisols and brinjal crop, Bulletin of Environmental Contamination and Toxicology, 83(3), 2009, 348-351.

[32] R. Chauhan and B. Kumari, Reduction of endosulfan residues in brinjal fruits during processing, Sci. Revs. Chem. Commun, 1 (1), $2011,42-48$.

[33] M.A. Radwan, M.H. Shiboob, M.M. Abu-Elamayem and A. Abdel-Aal, Residues of pirimiphos-methyl and profenophos on green pepper and eggplant fruits and their effect on some quality properties, Emir. J. Agric. Sci., 16 (1), 2004, 32-42.

[34] P.N. Waghulde, M.K. Khatik, V.T. Patil, P.R. Patil, Persistence and dissipation of pesticides in chilly and okra at north Maharashtra region, Pesticide Research Journal, 23 (1), 2011, 23-26.

[35] S.K. Sahoo, Dissipation kinetics of flubendiamide on chilli and soil, Bulletin of Environmental Contamination and Toxicology, 83, 2009, 384-387.

[36] S.K. Das, I. Mukherjee and S.K. Das, Dissipation of flubendiamide in/on okra (Abelmoschus esculenta (L.) Moench) fruits, Bulletin of Environmental Contamination and Toxicology, 88 (3), 2012, 381-384.

[37] A. Duhan, B. Kumari and R. Gulati, Effect of Household Processing on Fenazaquin Residues in Okra Fruits, Bulletin of Environmental Contamination and Toxicology, 84(2), 2010, 217-220. 
[38] B.K. Kang, G. Jyot, R.K. Sharma, R.S. Battu, B. Singh, Persistence of propargite on okra under subtropical conditions at Ludhiana, Punjab, India, Bulletin of Environmental Contamination and Toxicology, 85(4), 2010, 414-418.

[39] S.K. Sahoo, G.S. Chahil, K. Mandal, R. S. Battu, B. Singh, Estimation of $\beta$-cyfluthrin and imidacloprid in okra fruits and soil by chromatography techniques, J Environ Sci Health Part B, Pesticides Food Contaminants and Agricultural Wastes; 47(1), 2013, 4250 .

[40] R. Chauhan, S. Monga, B. Kumari, Dissipation and decontamination of bifenthrin residues in tomato (Lycopersicon esculentum Mill), Bulletin of Environmental Contamination and Toxicology, 89(1), 2012c, 181-186.

[41] J. Holland and P. Sinclair, Environmental fate of pesticides and the consequences for residues in food and drinking water, In Hamilton D. \& Crossley S. (Ed.) Pesticide Residues in Food and Drinking Water: Human Exposure and Risks (John Willey \&Sons LTD, 2004), $27-62$.

[42] Md Shokrzadeh and SSS Saravi, Pesticides in Agricultural Products: Analysis, Reduction, Prevention, Prof. Margarita Stoytcheva (Ed.), Pesticides - Formulations, Effects, Fate, (2011) ISBN: 978- 953-307-532-7.

[43] B. M. Keikotlhaile, and P. Spanoghe (2011) Pesticide Residues in Fruits and Vegetables, Pesticides - Formulations, Effects, Fate, Prof. Margarita Stoytcheva (Ed.), ISBN: 978-953-307-532-7, InTech, Available from: http://www.intechopen.com/books/pesticidesformulations-effects-fate/pesticide-residues-in-fruits-and vegetables.

[44] P.E. Boon, H. Van der Voet, M.T.M. Van Raaij and J.D. Van Klaveren, Cumulative risk assessment of the exposure to organophosphorus and carbamates insectidies in the Dutch diet, Food Chem Toxicol, 46(9), 2008, 3090 - 3098.

[45] M. Boulaid, A. Aguilera , F. Camacho, M. Soussi and A. Valverde, Effect of household processing and unit-to-unit variability of pyrifenox, pyridaben, and tralomethrin residues in tomatoes, J Agri Food Chem, 53(10), 2005, 4054-4058.

[46] W.J. Krol, T.L. Arsenault, H. Pylypiw, and M.J. Incorvia Mattina, Reduction of pesticide residues on produce by rinsing, J Agri Food Chem, 48, 2000, 4666-4670.

[47] A. Zohair, Behavior of some organophosphorus and organochlorine pesticides in potatoes during soaking in different solutions, Food Chem Toxicol, 39, 2001, 751-755.

[48] P. Pugliese, J. C. Molto, P. Damiani, R. Marin, L. Cossignani and J. Manes, Gas chromatography evaluation of pesticide residue contents in nectarines after non-toxic washing treatments, Journal of Chromatography A, 1050, 2004, 185-191.

[49] Extension Toxicology Network (1996) Pesticide Information Profiles. Oregon State University. Retrieved from: http://ace.ace.orst.edu/info/extonet/ghindex.html. (Accessed on January 16, 2013).

[50] A. Ahmed, M. A. Randhawa, M. J. Yusuf and N. Khalid, Effect Of Processing On Pesticide Residues In Food Crops - A Review, Journal of Agricultural Research, 49(3), 2011, 379-390.

[51] S. Jayakrishnan, A.K. Dikshit, J.P. Singh and D.C. Pachauri, Dissipation of Lambda-Cyhalothrin on Tomato (Lycopersicon esculentum Mill.) and Removal of Its Residues by Different Washing Processes and Steaming, Bulletin of Environmental Contamination and Toxicology,75(2), 2005, 324-328.

[52] M.J. Chavarri, A. Herrera and A. Arino, Decrease in pesticides in fruits and vegetables during commercial processing, International Journal of Food Science and Technology, 40, 2005, 205-211.

[53] A. Bonnechère, V. Hanot, R. Jolie, M. Hendrickx, C. Bragard, T. Bedoret \& J. Van Loco, Processing Factors of Several Pesticides and Degradation Products in Carrots by Household and Industrial Processing, Journal of Food Research, 1(3), 2012, 68-83.

[54] A.A. Panhwar and S.A. Sheikh, Assessment of pesticide residues in cauliflower through gas chromatography- $\mu$ ECD and high performance liquid chromatography (HPLC) analysis, International Journal of Agricultural Sciences and Research 3(1), 2013, 716.

[55] M. A. Randhawa, F. M. Anjum, M. S. Randhawa, A. Ahmed, U. Farooq, M. Abrar and A. R. Randhawa, Dissipation of Deltamethrin on supervised vegetables and removal of its residue by household processing, Journal of Chemical society of Pakistan, 30(2), 2008, 227-231.

[56] M.A. Randhawa, F.M. Anjum, A. Ahmed, M.S. Randhawa, Field incurred chlorpyrifos and 3,5,6-trichloro-2-pyridinol residue in fresh and processed vegetables, Food Chemistry, 103, 2007a, 1016-1023.

[57] S.A. Sheikh, S.M. Nizamani, A.A. Jamali, B.N. Mirani, A.A. Panhwar and M.J. Channa, Effect of Household Processing on the Removal of Pesticide Residues in Okra Vegetable, Journal of Basic and Applied Sciences 8, 2012, 74-78.

[58] S. S. Chauhan, S. Negi, N. Singh, G. Bhatia and A. Srivastava, Monitoring of pesticides residues in farmgate vegetables of Uttarakhand, India, Wudpecker Journal of Agricultural Research, 1(7), 2012a, 250 - 256.

[59] N. Thanki, P. Joshi and H. Joshi, Effect of household processing on reduction of reduction of pesticide residues in brinjal (eggplant, Solanum melongena), Adv. Appl. Sci. Res, 3(5), 2012a, 2860-2865.

[60] Gardenmo.net (2013) Retrieved from: http://www.gardenmo.net/vegetable-garden-2/decontamination-of-pesticide-residues-on-fruitsand-vegetables.html. (Accessed on: January 28, 2013).

[61] G. Sathpathy, Removal of organophosphorus (OP) pesticide residues from vegetables using washing solutions and boiling, Journal of Agricultural Sciences 4(2), 2012, 69-78.

[62] B. Kumari, Effects of household processing on reduction of pesticide residues in vegetables, ARPN J. Agricult. Biol. Sci. 3 (4), 2008, 46-51.

[63] Samriti, R. Chauhan and B. Kumari, Persistence and effect of processing on reduction of chlorpyrifos residues in okra fruits, Bulletin of Environmental Contamination and Toxicology, 87(2), 2011, 198-201.

[64] S. Zafar, A. Ahmed, R. Ahmad, M.A. Randhawa, M. Gulfraz, A. Ahmad and F. Siddique, Chemical residues of some pyrethroid insecticides in eggplant and okra fruits: effect of processing and chemical solutions, Chemical Society of Pakistan, 34(5), 2012, 11691178 .

[65] A.K. Dikshit, O.P. Lal, S.R. Sinha and Y.N. Srivastava, Safety evaluation, persistence and bioefficacy of imidachloprid and $\beta$ cyfluthrin on okra, Pestology 26, 2002, 30-37.

[66] S. Walia, P. Boora and B. Kumari, Effect of Processing on Dislodging of Cypermethrin Residues on Brinjal, Bulletin of Environmental Contamination and Toxicology, 84 (4), 2010, 465-468.

[67] P. Kaur, G.S. Yadav, R. Chauhan and B. Kumari, Persistence of cypermethrin and decamethrin residues in/on brinjal fruits, Bulletin of Environmental Contamination and Toxicology, 87(6), 2011, 693-698.

[68] K. Gill, B. Kumari and T. S. Kathpal, Dissipation of alphamethrin Residues in/on Brinjal and Tomato during Storage and Processing Conditions, Journal of Food Science and Technology, 38 (1), 2001, 43-46.

[69] A. Samanta, A. Chowdhury, A.K. Somchoudhury, Residues of Different Insecticides in/on Brinjal and Their Effect on Trichogramma spp., Pesticide Research Journal, 18 (1), 2006, 35-39.

[70] R.L. Naik, V.D. Kale and M.D. Dethe, Studies on residues of flufenzin and fenpyroximate on brinjal, International Journal of Plant Protection, 2(1), 2009, 38-41 
[71] R. Chauhan, S. Monga and B. Kumari, Effect of processing on reduction of $\lambda$-cyhalothrin residues in tomato fruits, Bulletin of Environmental Contamination and Toxicology, 88(3), 2012b, 352-357.

[72] K.M. Knio, A. Saad and S. Dagher, The fate and persistence of zineb, maneb, and ethylenethiourea on fresh and processed tomatoes, Food Additives and Contaminants, 17(5), 2000, 393-398.

[73] E.R. Elkins, Effect of commercial processing on pesticide residues in selected fruits and vegetables, Association of Official Analytical Chemists, 72(3), 1989, 533-535.

[74] C. Uysal-Pala and A. Bilisli, Fate of endosulfan and deltamethrin residues during tomato paste production, Journal of Central European Agriculture, 7 (2), 2006, 343-348.

[75] N. Dhiman, G. Jyot, A.K. Bakshi and B. Singh, Decontamination of various insecticide in cauliflower and tomato by different processing methods, Journal of Food Science and Technology, 43 (1), 2006, 92-95.

[76] A. Kar, K. Mandal, B. Singh, Decontamination of chlorantraniliprole residues on cabbage and cauliflower through household processing methods, Bulletin of Environmental Contamination and Toxicology, 88(4), 2012, 501-506.

[77] N. Thanki, P. Joshi and H. Joshi, Effect of household processing on reduction of reduction of pesticide residues in Cauliflower (Brassica oleraceae var. botrytis), European Journal of Experimental Biology, 2 (5), 2012b, 1639-1645.

[78] Md. W. Aktar, D. Sengupta, S. Purkait and A. Choudhary, Risk assessment and decontamination of quinalphos under different culinary processes in/on cabbage, Environ Monit Assess, 163, 2010, 369-377.

[79] A. Yang, J.H. Park, A.M.A. El-Aty, J.H. Choi, J.H. Oh, J.A. Do, K. Kwon, K.H. Shim, O.J. Choi and J.H. Shim, Synergistic effect of washing and cooking on removal of multi-classes of pesticides from various food samples, Food Control, 28, 2012, 99-105.

[80] M.A. Randhawa, F.M. Anjum, M.R. Asi, M.S. Butt, A. Ahmed and M.S. Randhawa, Removal of endosulfan residues from vegetables by household processing, J Scient Indust Res, 66, 2007b, 849-852.

[81] Y. Liang, W. Wang, Y. Shen, Y. Liu and X.J. Liu, Effects of home preparation on organophosphorus pesticide residues in raw cucumber, Food Chemistry, 133, 2012, 636-640.

[82] T.H. Hanumantharaju and M.D. Awasthi, Effect of decontamination processes on fungicide residues in tomato fruits, Journal of Food Science and Technology, 40(4), 2003, 374-377.

[83] H. Das, S. Jayaraman and M. Naika, Decontamination of residues of fungicides carbendazim in tomato and apple by dip treatments. Journal of Food Science Technology, 40(5), 2003, 538-542.

[84] C. Lentza-rizos and A. Balokas, Residue levels of chlorpropham in individual tubers and composite samples of post-harvest treated potatoes, J Agricult. Food Chem, 49 (2), 2001, 710-714.

[85] M. F. Cengiz, M. Certel, B. Karakas and H. Gacmen, Residue contents of DDVP (Dichlorvos) and Diazinon applied on cucumbers grown in greenhouses and their reduction by duration of a pre-harvest interval and post-harvest culinary applications, Food Chemistry, 98, 2006, 127-135.

[86] A. Dehghan, M. Ghorbani, Y. Maghsoudlou, S.S. Saravi, Z.A. Babaee and M. Shokrzadeh, Effects of Washing, Peeling, Storage and Fermentation on Residue Contents of Malathion and Diazinon in Cucumbers Grown in Greenhouses, Food Chemistry, Accepted, 2010 .

[87] M. F. Cengiz, M. Certel, B. Karakas and H. Gacmen, Residue contents of captan and procymidone applied on tomatoes grown in greenhouses and their reduction by duration of a pre-harvest interval and post-harvest culinary applications, Food Chemistry, 100, 2007, 1611-1619.

[88] O. Pardez-Lopez, Gonzales-Casteneda and A.J. Carabenz-Trejo, Influence of solid substrate fermentation on the chemical composition, Journal of Fermentation and Bioengineering 71, 1991, 58-62.

[89] M. Shokrzadeh and S.S.S. Saravi, Measurement of residues of benomyl and mancozeb pesticides in shrub and nonshrub cucumbers sampled from different regions of Mazandaran province (Iran), Toxicol Environ Chem, 91(4), 2008, 627-630.

[90] A. Azizi Bacterial-Degradation of Pesticides Residue in Vegetables during Fermentation, Margarita Stoytcheva (Ed.), PesticidesFormulations, Effects, Fate (2011) ISBN: 978-953-307-532-7.

[91] G. Kaushik, S.N. Naik and S. Satya, Food processing a tool to pesticide residue dissipation - a review. Food Res Int, 42, 2009, 2640 .

[92] C.Z. Zhang, A.L. Luo, D.L. Wang and X.J. Liu, Degradation method of Beta-cypermethrin residue on Greengrocery, Journal of Agro-Environment Science, 24, 2004, 196-200. 